\title{
BRAIN DRAIN: ARE WE LOSING OUR MINDS? A STUDY ON THE ROMANIAN HUMAN CAPITAL F(L)IGHT
}

\author{
Delia POP FLANJA \\ Lecturer, Ph.D. \\ Faculty of European Studies, \\ Babeș-Bolyai University Cluj-Napoca \\ delia.flanja@ubbcluj.ro \\ Roxana-Maria NISTOR (GÂZZ) \\ Assistant Professor (ESP, EAP), Ph.D. \\ Faculty of Letters, \\ Babeș-Bolyai University Cluj-Napoca \\ roxana.nistor@ubbcluj.ro
}

\section{DOI:10.24193/OJMNE.2017.24.05}

\begin{abstract}
In a truly internationalised world, where the mobility of workers and students is encouraged, the transfer of skilled individuals (geographical brain drain) is a problem that affects many of the developing countries around the globe. The purpose of our research is to see whether Romania is still a country strongly affected by the geographical brain drain, as well as to find out the reasons behind the intention to seek employment abroad. As such, we wanted to find out if the students enrolled at the Faculty of European Studies within Babeș-Bolyai University already know what they want to do after graduation, i.e. leave the country / stay in their country of origin, and to find out to what extent the possibility to study abroad for one semester or a year through the Erasmus + Programme or to go on a 'Work \& Travel' programme influences students' decision of leaving the country after graduation.
\end{abstract}

Keywords: brain drain, human capital flight, employment, study mobility, work and travel mobility, Romanian students 
Issue no. $24 / 2017$

\section{Introduction}

In a globalised world, where the movement of workforce is commonplace nowadays, so is the transfer of (highly) skilled individuals from one region to another or from one country to another. More commonly known as brain drain, this phenomenon affects most of the countries of the world, and increasingly more people are tempted to leave their country of origin in search of better opportunities, of a better place for their professional and personal development.

It is also the case of Romania, which has been, in the past decade or so, one of the European countries that has been increasingly marked by this large-scale phenomenon. Romanians of all ages and educational backgrounds have decided to leave their homeland to find better job opportunities.

Starting from the concept of the geographical brain drain of highly skilled individuals, the purpose of our study is see whether the students enrolled at the Faculty of European Studies within Babeș-Bolyai University already have an idea of what they want to do once they graduate, i.e. leave or stay in their country of origin, as well as to find out to what extent the possibility to study abroad for one semester or a year, or to go on a 'work \& travel' programme influences students' decision of leaving the country after graduation.

\section{Literature Review}

Brain drain has been a long-discussed topic. It was initially used by the British Royal Society to refer to the exodus of European intellectuals to the USA and Canada in the ' $50 \mathrm{~s}$ and the '60s (Cervantes and Guellec, 2002), as World War II and the Nazi politics of exterminating Jews led to the emigration of many intellectuals to the American continent in order to escape the persecution (Gâz 2012: 116). Since then, a lot of scholars have focused on the negative aspects of it or, starting from the '90s, on its (possible) positive aspects and its solutions (Kwok and Hayne, 1982; Ranis et al. 2000; Adams, 2003; Mahroum, 2005; Çaglar \& Schiff, 2006).

Over the years, the meaning of the term has changed and does not only refer to the migration of highly educated individuals from one country to another, but also to their movement from one region to another or from one city to another. Similar terms are brain 
Issue no. $24 / 2017$

circulation and brain waste, but some scholars consider these terms pejorative and recommend the usage of the term human capital flight (Pistone et al., 2007).

The Oxford Dictionary defines the term as "the emigration of highly trained or qualified people from a particular country", while the Merriam Webster Dictionary provides a more detailed explanation, stating that brain drain represents indeed the emigration of highly skilled individuals, but it also adds the possible reasons for this: "the departure of educated or professional people from one country, economic sector, or field for another usually for better pay or living conditions". According to these definitions, brain drain can be classified as geographical (the departure of individuals from one country to another to find better living conditions and better paid jobs), industrial (the departure of employees from one economic sector to another) or organisational (de departure of employees from one company to another). We shall refer in this article to the geographical brain drain.

Some scholars believe that the most educated people are the ones most tempted to migrate (Mora \& Taylor, 2006; Dustmann \& Glitz, 2011). Docquier and Rapoport (2012), for instance, some state that the term brain drain is used to refer to "the migration of engineers, physicians, scientists, and other very highly skilled professionals with university training". They also state that "a brain drain can induce occupational shortages in certain sectors and professions (e.g., teachers, engineers, physicians, nurses)" (Docquier and Rapoport, 2012: 698).

In 1951, the "push-pull" basic change model was introduced by Lewin. According to this change model, there are factors pushing professionals from their home country and factors that pull the professionals to a host country. This model introduced by Lewin also refers to intermediary stages: unfreeze, transition, and refreeze. In a later study, Ambrosini et al. (2015) consider that migrants can be assigned to two categories: high-skill cells and lowskill cells. These skill cells are defined by the migrants' level of education, age and gender. According to Ambrosini et al., in the case of Romania, highly skilled individuals prefer to emigrate to "traditional immigration countries (US, Canada, and Australia)" mostly for educational purposes (Ambrosini et al., 2015: 758), but also because such developed countries offer higher wages than other less-developed countries. "The number of Europeans going to North America is double those arriving from there" (Mahroum 1999: 21). 
Issue no. $24 / 2017$

Some authors see a silver lining in brain drain: they do not think of this process as a loss for the country of origin, but as a gain for both the host country and the sending country, namely the beneficial brain gain (Mountford, 1997; Stark, Helmenstein, and Prskawetz, 1997, 1998; Beine, Docquier, and Rapoport, 2001, 2003). This brain gain could translate, for instance, into a powerful Diaspora or in remittances for the home country (Çaglar \& Schiff, 2006).

\section{Current Situation in the World and in Romania}

The United Nations has recently published a report on the World Population Prospects, mentioning that, in 2017, there are more than 7.5 billion people living in the world, only $10 \%$ of them living on the European continent. Although the world population is projected to grow slightly but constantly by 2060, the European population will see a decrease while "Africa will be the main contributor to the global population growth" (UN, 2017: 3). In contrast to the African continent, several European countries are expected to register a decline in the number of their citizens, and Romania is one of them.

According to a recent Eurostat survey, in 2015, 1.9 million European citizens migrated from their country of origin to another EU member-state, the Romanian citizens accounting for one of the largest shares of migrant population (Eurostat, 2016). The same survey reports that, as of 1st January 2016, "there were 16.0 million persons living in one of the EU Member States on 1st January 2016 with the citizenship of another EU Member State" (Eurostat).

In 1950, Romania registered a population of more than 16 million people. By 2017, the number has increased by more than 15 reaching 19,679,000 inhabitants. This last number is likely to gradually decrease, so that by 2030 the number of inhabitants of Romania will be of roughly 18.5 million inhabitants, $16,397,000$ inhabitants by 2050, and an alarming number of 12,082,000 inhabitants by 2100 (UN, 2017: 26). The reasons for this steady decrease are detailed in a document drafted and issued by the Romanian National Institute for Statistics (INS), and they are: the fertility rate / birth rate, the mortality rate, but the most important one is the international migration. This last factor is described by the INS as a "demographic phenomenon whose evolution is directly dependent on the force of the factors specific to the 
'attraction / rejection' mechanism, which are predominantly economic"4 (INS, 2017: 19). As such, citizens decide to emigrate to more developed countries, where the living standard is higher than in Romania, in order to find better jobs and better living conditions: "the profound transformations in the legislative system and the free movement of people represent the premises for the sharp increase in the level of international migration" (INS, 2017: 19).

Generally speaking, some of the most important causes of brain drain refer to the social and economic situations existing in the emigrants' country of origin. If citizens do not have the proper economic, political, social and educational environment, they will leave to other countries to find a better job, better living conditions. "The majority - doctors, engineers, lecturers, researchers and senior managers as well as students - are tempted by more attractive career opportunities, salaries and living conditions. A university degree is also the safest passport out of an unstable political environment.” (UNESCO, 2006--2007: 4).

It is the case of Romania and of its highly skilled citizens. According to a European study on the movement of skilled individuals carried out between 2003 and 2014, Romania ranks on an "unfortunate third place, after Poland and Germany" (Pop-Flanja, 2015: 29). The survey analyses the destinations preferred by the EU-born migrants as well as the "most mobile brains in the EU since 2003". As such, it seems that the most mobile individuals, according to their profession, since 2003, have been secondary school teachers, doctors, nurses, physiotherapists, and dentists. In the case of Romania, for the period of time ranging from Romania's access to the European Union until 2016, according to the EU Ranking for Temporary Mobility, it seems that the most mobile 'brains' were secondary school teachers, ski instructors, physiotherapists, veterinary surgeons, radiographers / radiotherapists, dentists and doctors of medicine, pharmacists, architects, nurses, and civil engineers (EU "Overall statistics on temporary mobility"). We also have statistics showing the countries preferred by the migrant population once they obtained their degree: Germany (20\%), the UK (17\%), Denmark (14\%), Italy (14\%), France (10\%), and other countries (25\%) (EU "Overall statistics on temporary mobility").

\footnotetext{
${ }^{4}$ Authors' translation.
} 
Issue no. $24 / 2017$

\section{Erasmus+ Study Mobilities and Work \& Travel Programmes}

Erasmus+ and Work \& Travel offer temporary mobility programmes and their purpose is not that of 'stealing' highly skilled students, but that of offering them a new life experience that can open their minds and broaden their perspective. Both programmes commit to sending students back to their country of origin. One of the documents posted on the website of the Education, Audiovisual and Culture Executive Agency (EACEA) operating under the auspices of the European Commission, referring to the Erasmus Mundus Programme, even addresses the issue of the possible brain drain, stating that "all participating institutions commit themselves not to carry out any activity susceptible of encouraging the brain drain (for example, offering jobs or further possibilities to study in the hosting university)" (EACEA, 2007).

In the Decision No. 1298/2008/EC of the European Parliament and of the Council of 16 December 2008 establishing the Erasmus Mundus 2009-2013 action programme for the enhancement of quality in higher education and the promotion of intercultural understanding through cooperation with third countries, article 9 talks about the quality of the European higher education, the understanding between peoples around the world, as well as about the sustainable development of higher education which can only be achieved through "integrated study programmes (...) at all levels of study, (...) scholarships for the most talented students and projects to enhance the worldwide attractiveness of European higher education", while "the Commission should pay particular attention to its potential brain drain effects" (Official Journal of the European Union, 2008).

The Erasmus Impact Study - A Comparative Analysis of the Effects of Erasmus on the Personality, Skills and Career of students of European Regions and Selected Countries, published by the European Commission in 2016, presents an analysis of the impact of the Erasmus+ Programme, identifying the regional aspects in the effects of student mobility on employability, careers, skills and social lives of students from Northern, Southern, Western and Eastern Europe (EU, Erasmus Impact Study, 2016). According to the study, "at least 90\% of Erasmus students in all regions participate in Erasmus in order to experience living abroad, meet new people, learn or improve a foreign language and develop their soft skills" followed by the "wish to enhance employability abroad (87\%), which is more important than 
Issue no. $24 / 2017$

employability at home (77\%)" (EU, Erasmus Impact Study, 2016: 13). The motivations of students to go abroad are slightly different throughout the regions. Whereas for NorthEuropean and West European students the focus is primarily on living abroad and meeting people, students in Eastern Europe primarily choose to go abroad to improve their foreign language skills and to broaden their career prospects. Of all the regions, students in Southern Europe have the highest motivation to participate in the programme in order to increase their future employability abroad. Even if the main purpose of the programme is study mobility, the study shows that "Erasmus promotes labour mobility after graduation. Of the Erasmus alumni, $40 \%$ had moved country at least once since graduation compared with $23 \%$ of nonmobile alumni. In addition, 93\% (compared with $73 \%$ of the non-mobile students) could envisage living abroad." (EU, Erasmus Impact Study, 2016: 19).

Hence, we have a clear correlation between this type of study mobilities and the increased perspective of relocating and labour mobility after graduation is envisaged as well. Participating in such mobility programmes can contribute to the development of cultural characteristics such as indulgence, one of the characteristics that is considered to play a "causal role in social development processes" (Dan, 2017: 119). However, although we cannot argue that there is a wider range of employment opportunities due to the increase in certain skills required on the labour market, the question that we are trying to address in the case study of this article is whether it is the mobility per se that determines the increased numbers from this point of view, or is it that mobile students already have this availability for working abroad prior to the mobility, and it is this availability that actually determines them to take part in the Erasmus programme to begin with.

While the Erasmus+ Programme is meant to foster students' mobility to have a study experience abroad, the Work \& Travel USA Programme has as purpose to offer full-time students the possibility to work in the USA for a limited period of time. Compared to the Erasmus+ Programme that puts emphasis on study and cultural exchange opportunities, Work \& Travel USA is aimed at offering work / money-related opportunities or an intercultural experience. Erasmus+ gives students the possibility to benefit from a study period in one of the countries around the world that is part of this worldwide community, while Work and 
Issue no. $24 / 2017$

Travel USA offers them the possibility to work for a short period of time, usually during summer, up to four months (Work and Travel USA official website).

\section{Research Findings}

As previously stated, the main aim of the study is to analyse the underlying factors that contribute to the graduates' intentions to pursue a career abroad and to what extent it is strictly determined by their participation in study mobility programmes or international cultural exchange programmes such as Work and Travel, particularly whether or not they already have an intention to find employment abroad before actually taking part in such programmes. Should the hypothesis be confirmed by the results, participating in mobility or exchange programmes contributes to reinforcing or not the intention, to increasing accessibility or it directs the individuals towards certain destinations, without actually being at the core of brain circulation.

\section{a. Methodology}

The research design chosen for this study is the quantitative method. However, elements of the qualitative method, such as participant observation, have also been used. The results have been interpreted using the SPSS (Statistical Package for the Social Sciences) software.

The survey, consisting of a questionnaire having both closed and open-ended questions, was applied on 157 first-year Bachelor's degree students of the Faculty of European Studies, Babeş-Bolyai University of Cluj-Napoca, representing $48 \%$ of the total number of students enrolled in the first year for full-time studies at the faculty. The reason for selecting this group is the international profile of the faculty and the wide network of international cooperation agreements, in proportion to the number of students of the faculty. More precisely, the faculty has more than 80 Erasmus+ bilateral agreements and a number of approximately 1400 students, Bachelor's, Master's, and doctoral levels. The specialisations chosen for the study are International Relations and European Studies, full time programmes offered in Romanian, English and German, as well as European Administration (in Romanian). Therefore, the study used the following selection criteria: a participant had to be 
a first-year student, not to have taken part in Erasmus+ or Work and Travel study mobility and cultural exchange programmes, to be enrolled full-time in one of the above-mentioned specializations of the Faculty of European Studies, not to know the purpose of the survey, to be in the age group 18-25. Only one of the participants did not comply with the criteria, and, being outside the age group envisaged, he was excluded from the study, as the factors that might have contributed to the answers given were considered more diverse.

\section{b. Results}

A specific objective of the study was to analyse whether the students' language of study influences their choices of participating in study mobility programmes, in international cultural exchange programmes, or of relocating abroad, whether students enrolled in full-time programmes in a foreign language are more prone to undergoing such activities.

The results show that there is no direct correlation between the intention of the students to seek employment upon graduation in Europe or in non-European countries and the language of instruction. As to what the percentages of the respondents who expressed the intention to seek employment in a European country other than Romania is concerned, $60 \%$ of the students from the Romanian line of study expressed this interest, 64\% from the English one and $45 \%$ from the German one. Similarly, the percentages for those declaring the intention to seek employment in a non-European country are of $26 \%$ for the Romanian line of study, $25 \%$ for the English one and $9 \%$ for the German one. Hence, apart from a slightly smaller percentage of the students from the German line that expressed an intention to work abroad upon graduation, studying in a foreign language does not represent a factor to influence the decision of the surveyed population of students from this point of view. 
Issue no. $24 / 2017$

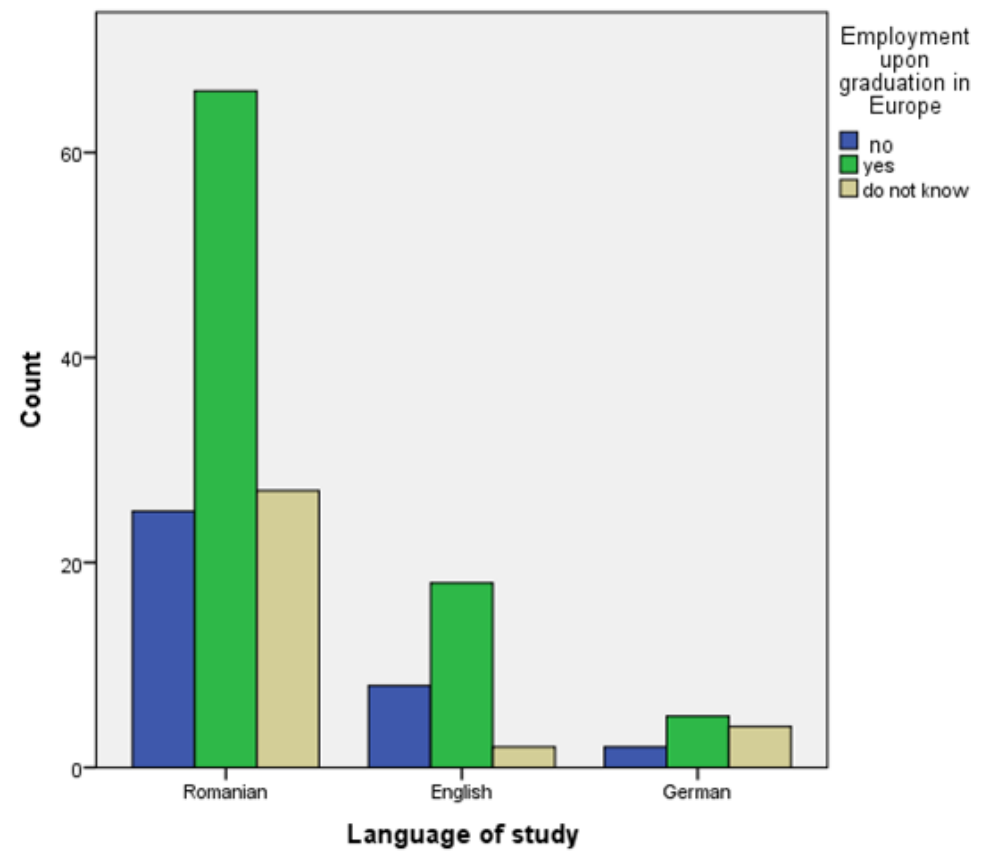

Table 1. Correlation: Language of study - Employment in other European countries

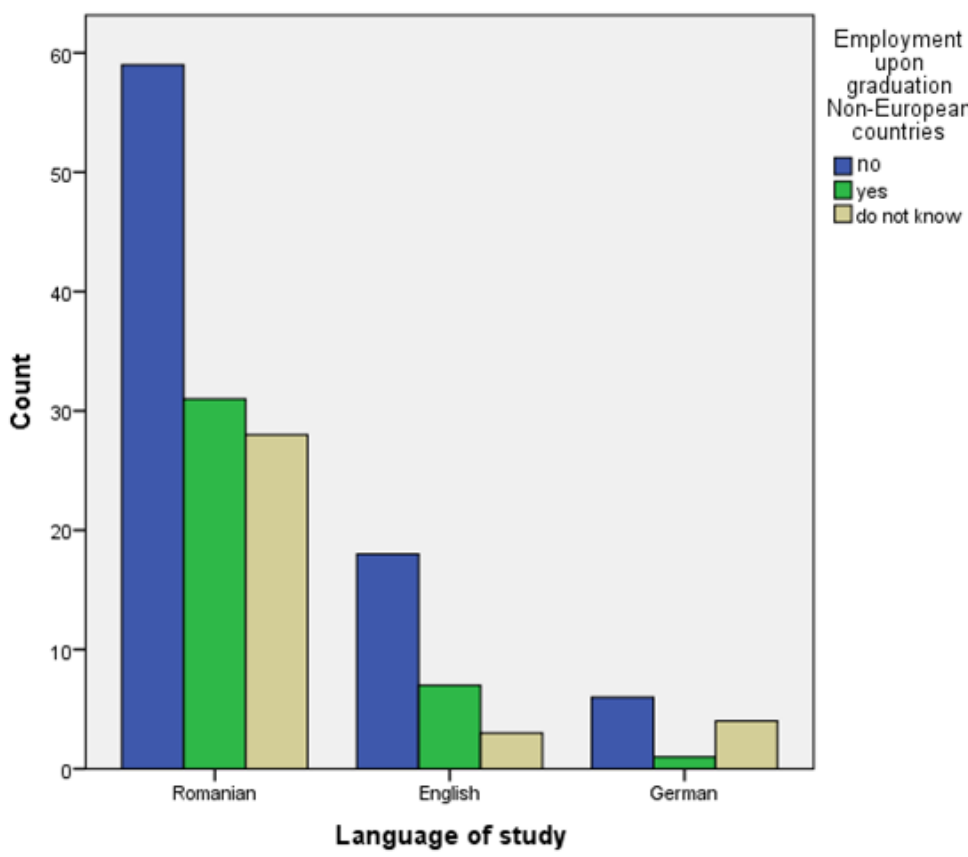

Table 2. Correlation: Language of study - Employment in a non-European country 
Issue no. $24 / 2017$

Next, we are going to present the results related to the intention of the surveyed students to seek employment upon graduation in Romania, in another European country or in a non-European country. The responses revealed that the intention to seek employment in Romania was expressed by $38.9 \%$ of the respondents, whereas $40.1 \%$ declared not having this intention and $21 \%$ being undecided. As to what working in other European countries is concerned, $56.7 \%$ answered yes, $22.3 \%$ said no and $21 \%$ chose I do not know as option to answer. As estimated, the situation for the choice of a non-European country is different, with only $24.8 \%$ expressing an interest in those areas. This choice can be explained by the capacity to adapt to a more contrasting non-European environment or by proximity reasons. The degree of uncertainty in this intention was also slightly higher, of $22.3 \%$.

The respondents that declared being undecided in their intention to seek employment in a certain geographical area were roughly the same for all three categories, the reasons being mostly the lack of knowledge on what opportunities and perspectives might be offered by any of the above-mentioned areas.

Out of the 33 respondents who were undecided regarding seeking employment in another European country, 28 expressed an intention to take part in student mobility programmes, which means that there is an availability towards a medium term international experience. It is to this category that a future decision of relocating abroad could be considered as being mostly determined by the future intercultural experiences that they might have, such as a future Erasmus+ mobility. However, as the factors that may influence their decisions are complex, what we plan to analyse is solely the intention expressed.

Next, we are going to present the results on the reasons presented by the surveyed students in support of their interest into studying abroad. As this was an open-end question, the students had the opportunity to answer freely, without particular reasons being suggested to them. In order to interpret the results, we have grouped their answers in different categories, based on the degree of occurrence. As the graph below shows, out of the 89 students that presented an interest into working in a European country (57\% of the total number of respondents), 27 focused on the general opportunities and perspectives that a foreign European country can offer. Financial reasons were mentioned by other 27 respondents, but additionally to the opportunities, perspectives, personal and professional 
development. We are aware that the opportunities and perspectives offered by a foreign country may also refer to the personal or professional development, depending on what each respondent understood by these terms, but we have decided to keep the exact terms used by them, for accuracy purposes.

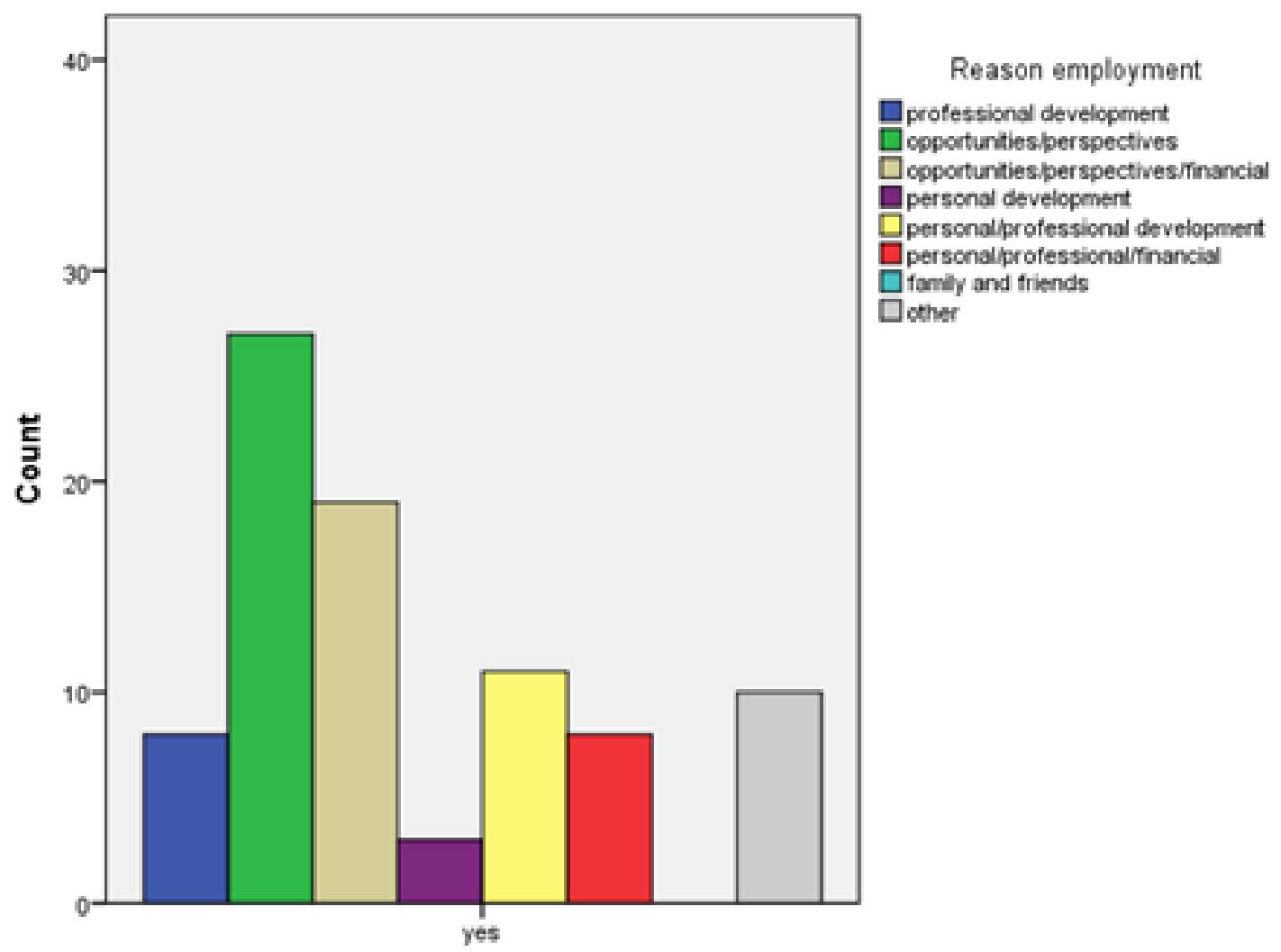

Employment in Europe, upon graduation

Table 3. Reasons for seeking employment upon graduation in other European countries

As for the 35 respondents that declared not having an interest into studying in a foreign European country, the main reasons presented were the family and friends that they have in Romania, as well as the opportunities and perspectives that Romania can offer them.

Regarding the intention of the respondents to study abroad, $81 \%$ of the students showed an interest into taking part in a study mobility through the Erasmus+ programme. The reasons for their options are as follows: $67 \%$ for travel purposes and for getting familiar to 
new cultures/new people, $61 \%$ for personal development and new experiences, $54 \%$ for academic/professional development and of their language competencies, and less than $2 \%$ for relocation purposes. Hence, this type of study mobilities are being perceived more as a means of cultural awareness, of visiting new countries and personal development, and less as a means of enriching knowledge in the field of study. Relocation purposes were not clearly presented as being a strong reason for most of the respondents.

This aspect, correlated with the big number of respondents that showed an interest into working abroad, can lead to the assumption that students do not perceive Erasmus+ mobilities as a doorway towards working abroad, but more as a means of being more culturally aware, of developing mostly personally but also professionally, though to a smaller extent. What we can notice is more of an availability towards finding out what opportunities might be available for them, than a clear intention to seek employment or relocate abroad.

A big number of students also expressed the intention to take part in the Work and Travel USA programme, more precisely $60 \%$, whereas $30 \%$ declared not being interested into this programme, and only $10 \%$ not knowing about this programme. Among the reasons for taking part in the programme, the most common ones were travelling and knowing new people or cultures with $74 \%$, personal development $46 \%$, financial reasons $27 \%$ and professional development, including language acquisition, 25\%. Only one respondent presented relocation as a reason for participating in the programme. We did not identify a causal relation between students' interest into participating in the Work and Travel USA programme and their interest into finding employment in a non-European country upon graduation, as $48 \%$ of the respondents interested in the programme declared not having such an employment intention, $30 \%$ declared that they do have such an intention and $20 \%$ were undecided. However, we have estimated these results because, as previously mentioned, choosing a non-European country implies a higher degree of availability to adapt to a more contrasting cultural environment and to a more remote destination. 
Issue no. $24 / 2017$

\begin{tabular}{|c|c|c|c|c|}
\hline \multirow{2}{*}{\multicolumn{2}{|c|}{ Total: 157 respondents }} & $\begin{array}{l}\text { Employment in } \\
\text { Romania }\end{array}$ & $\begin{array}{l}\text { Employment in other } \\
\text { European countries }\end{array}$ & $\begin{array}{l}\text { Employment in Non- } \\
\text { European countries }\end{array}$ \\
\hline & & yes & yes & yes \\
\hline $\begin{array}{l}\text { Intention to study } \\
\text { abroad }\end{array}$ & yes & 50 & 80 & 36 \\
\hline $\begin{array}{l}\text { Intention to go on } \\
\text { Work and Travel USA }\end{array}$ & yes & 36 & 57 & 29 \\
\hline
\end{tabular}

Table 4. Correlation: Intention to study abroad and to participate in the Work and Travel USA programme - Intention to seek employment abroad upon graduation

To sum up the findings of our study pertaining to the intention of the surveyed student population of the Faculty of European Studies to study abroad, to take part in the Work and Travel USA programme, to seek employment abroad upon graduation, and how these variables interrelate, we can state that the respondents expressed a big interest in studying abroad and a rather big interest in participating in the Work and Travel USA cultural exchange programme, the most common programme of this type among the students of this faculty. More than half of them also expressed an interest in seeking employment abroad, in another European country, more than those expressing an interest into their home country.

Taking into consideration the fact that none of the respondents took part in a study exchange programme prior to responding to the survey, we can conclude that their availability from this point of view is not determined by the mobility, but that it already exists, and that their openness towards having an international experience is high. Hence, although our study is based on the intentions declared by the students and not on specific facts, we can still state that participating in mobility or exchange programmes contributes more to increasing accessibility, raising cultural awareness and knowledge, it is more the context than the cause of human capital flight among the young graduates in this field of study.

This paper should be interpreted as an initial stage in a more complex research, the next envisaged step being an analysis of the current situation of students' intentions to study and work abroad at the level of other faculties within Babeş-Bolyai University. 
Issue no. 24/2017

\section{Conclusions}

The international migration of skilled individuals has shaped both the home country and the host country, imprinting on them either a phenomenon of brain drain or one of brain gain. Although the departure of professionals from their country of origin might have, according to some authors, certain advantages (e.g. remittances for the home country), the brain drain phenomenon is unquestionable and has many negative consequences at least on the economy of the sending country.

Study mobility programmes, such as Erasmus+, or international cultural exchange programmes, such as Work and Travel USA, are not a cause of concern when it comes to 'losing the minds', to losing the (highly) skilled population of certain countries. These programmes have the purpose of increasing awareness on what the world has to offer, and they represent one of the benefits of internalization upon individuals, whatever the impact on the home country might be. If there is an intention of young graduates to seek employment or to relocate abroad, this intention is determined by the incapacity of their home countries to respond properly to their needs and expectations when it comes to professional or personal development.

\section{Bibliography}

\section{Books and Articles:}

1. AMBROSINI, J.W.; MAYR, K.; PERI, G.; RADU, D. (2015). The selection of migrants and returnees in Romania: Evidence and long-run implications. Economics of Transition. vol. 23. no. 4. pp. $753-793$.

2. BEINE, M.; DOCQUIER, F.; RAPOPORT, H. (2001). Brain Drain and Economic Growth: Theory and Evidence. Journal of Development Economics. Vol. 64(1), pp. 27589.

3. ÇAGLAR, O.; SCHIFF, M. (2006). International Migration, Remittances, and the Brain Drain. Washington: The World Bank, New York: Palgrave Macmillan. 
4. DAN, H. (2017). Is Social Progress Subject to Cultural Influences? Arguments for Considering Cultural Characteristics as Inputs for Social Policy Design and Implementation. On-line Journal Modelling the New Europe. No. 22, pp. 104-122.

5. DOCQUIER, F.; RAPOPORT, H. (2012). Globalization, Brain Drain, and Development. Journal of Economic Literature. Vol. 50, No. 3, September 2012. pp. 681-730.

6. DUSTMANN, C.; GLITZ, A. (2011). Migration and Education. Handbook of the Economics of Education. Vol. 4, pp. 327-439.

7. GÂZ, R. (2012). The Supremacy of English. A Challenge for the European Union. Studia UBB. Europaea. Issue 2/2012, pp. 109-134.

8. INSTITUTUL NAȚIONAL DE STATISTICĂ (2017). Proiectarea populaţiei României în profil teritorial la orizontul anului 2060. Bucureşti: Editura Institutului Naţional de Statistică.

9. KWOK, V.; HAYNE, L. (1982). An economic model of the brain drain. American Economic Review. No. 72, pp. 91-100.

10. LEWIN, K. (1951). Field theory in social science. NY: Harper \& Row.

11. MAHROUM, S. (2005). The international policies of brain gain: a review. Technology Analysis and Strategic Management. No. 17, pp. 219-230.

12. MAHROUM, S. (1999). Skilled Labour (Competing for the Highly Skilled: Europe in Perspective). Science and Public Policy. No 26, pp. 17-25.

13. MORA, J.; EDWARD TAYLOR, J. (2006). Determinants of Migration, Destination, and Sector Choice: Disentangling Individual, Household, and Community Effects. International Migration, Remittances, and the Brain Drain. Washington: The World Bank, New York: Palgrave Macmillan, pp. 21-51.

14. MUIJS, D. (2004). Doing Quantitative Research in Education: with SPSS. London: Sage Publications.

15. MOUNTFORD, A. (1997). Can a Brain Drain Be Good for Growth in the Source Economy? Journal of Development Economics. Vol. 53(2), pp. 287-303.

16. NEUMAN, LAWRENCE (2007). Basics of Social Research, Qualitative and Quantitative Approaches. 2nd edition. Boston: Pearson Education Inc. 
17. PISTONE, M.; HOEFFNER, J. J.; SCAPERLANDA, A. M. (2007). Stepping Out of the Brain Drain: Applying Catholic Social Teaching in a New Era of Migration. Lanham, MD: Lexington Books.

18. POP - FLANJA, D. (2015). Europe 2020 Strategy - Responding to (Un)Employment with Education. Studia Universitatis Babeș-Bolyai, Studia Europaea. Issue 4/2015, pp. 19-34.

19. RANIS, G.; STEWART, F.; RAMIREZ, A. (2000). Economic growth and human development. World Development. Vol. 28, issue 2, pp. 197-219.

20. STARK, O.; HELMENSTEIN, C.; PRSKAWETZ, A. (1997). A Brain Gain with a Brain Drain. Economics Letters. Vol. 55(2), pp. 227-34.

\section{Online resources:}

1. ADAMS, R.H. (2003). International migration, remittances, and the brain drain: a study of 24 labour exporting countries. World Bank Policy Research Working Paper WPS 3069. Available at http://documents.worldbank.org/curated/en/406641468757221102/pdf/multi0page.pdf [accessed on 24/11/2017].

2. CERVANTES, M.; GUELlEC, D. (2002). The Brain Drain: Old Myths, New Realities. OECD Observer, No. 230, January. Available at http://oecdobserver.org/news/archivestory.php/aid/673/The brain_drain:_Old_myths, ne w_realities.html, [accessed on 24/11/2017].

3. EDUCATION, AUDIOVISUAL AND CULTURE EXECUTIVE AGENCY (2007). Erasmus Mundus "External Cooperation Window". Questions and Answers. http://eacea.ec.europa.eu/extcoop/call/documents/faq.pdf [accessed on 25/11/2017].

4. EUROPEAN COMMISSION (2016). The Erasmus Impact Study - A Comparative Analysis of the Effects of Erasmus on the Personality, Skills and Career of students of European Regions and Selected Countries. Available at http://ec.europa.eu/dgs/education_culture/repository/education/library/study/2016/erasmu s-impact_en.pdf [accessed on 28/11/2017].

5. FACULTY OF EUROPEAN STUDIES website. http://euro.ubbcluj.ro/ [accessed on 03/11/2017]. 
Issue no. $24 / 2017$

6. MERRIAM WEBSTER DICTIONARY. Available at https://www.merriamwebster.com/dictionary/brain\%20drain?utm_campaign=sd\&utm_medium=serp\&utm_sou rce=jsonld [accessed on 24/11/2017].

7. OFFICIAL JOURNAL OF THE EUROPEAN UNION (2008). Decision. No 1298/2008/EC of the European Parliament and of the Council of 16 December 2008 establishing the Erasmus Mundus 2009-2013 action programme for the enhancement of quality in higher education and the promotion of intercultural understanding through cooperation with third countries. Available at http://eur-lex.europa.eu/legalcontent/EN/TXT/PDF/?uri=CELEX:32008D1298\&from=EN [accessed on 25/11/2017].

8. OXFORD DICTIONARY. Available https://en.oxforddictionaries.com/definition/brain_drain [accessed on 24/11/2017].

9. UNESCO (2006-2007). Education Today. The Newsletter of UNESCO's Education sector. No. 18. Available at http://unesdoc.unesco.org/images/0014/001477/147739e.pdf [accessed on 24/11/2017].

10. UNITED NATIONS, Department of Economic and Social Affairs, Population Division (2017). World Population Prospects: The 2017 Revision, Key Findings and Advance Tables. Working Paper No. ESA/P/WP/248. New York. Available at https://esa.un.org/unpd/wpp/Publications/Files/WPP2017_KeyFindings.pdf [accessed on 30/11/2017].

11. WORK AND TRAVEL USA website, https://www.workandtravelj1.com/ [accessed on 03/11/2017].

12. Movement in the EU: Countries to where the European brains move. Available at http://www.euroeduas.ro/wordpress/2015/10/17/movement-in-eu-countries-to-where-theeuropean-brains-move/ [accessed on 28/11/2017].

13. Overall Statistics on Temporary Mobility. Available at http://ec.europa.eu/growth/toolsdatabases/regprof/index.cfm?action=stat_overall\&b_services=true $\quad[$ accessed on 28/11/2017].

14. http://ec.europa.eu/eurostat/web/population-demography-migration-projections/statisticsillustrated, [accessed on 28/11/2017]. 